\title{
ANALYSIS OF SELECTED QUALITY FEATURES OF WOOD PELLETS
}

\author{
Józef Gorzelany ${ }^{\mathrm{a} *}$, Miłosz Zardzewiały ${ }^{\mathrm{b}}$, Piotr Murawskic ${ }^{\mathrm{c}}$, Natalia Matłok ${ }^{\mathrm{d}}$ \\ ${ }^{a}$ Department of Food and Agriculture Production Engineering, University of Rzeszow, Poland \\ ORCID 0000-0002-1028-097X \\ b Department of Food and Agriculture Production Engineering, University of Rzeszow, Poland \\ ORCID 0000-0002-8843-2814 \\ c Department of Food and Agriculture Production Engineering, University of Rzeszow, Poland, Student \\ ${ }^{d}$ Department of Food and Agriculture Production Engineering, University of Rzeszow, Poland \\ ORCID 0000-0003-3658-7176
}

* Corresponding author: e-mail: gorzelan@ur.edu.pl

\begin{tabular}{|c|c|}
\hline ARTICLE INFO & ABSTRACT \\
\hline $\begin{array}{l}\text { Article history: } \\
\text { Received: January } 2020 \\
\text { Received in the revised form: } \\
\text { February } 2020 \\
\text { Accepted: March } 2020\end{array}$ & \multirow{2}{*}{$\begin{array}{l}\text { The article presents an analysis of the energy, mechanical and chemi- } \\
\text { cal properties of pellets made of wood material. According to the } \\
\text { manufacturer, wood pellets were made of hard wood shredded to } \\
\text { fractions approx. } 1 \mathrm{~mm} \text { thick and up to } 3-4 \mathrm{~mm} \text { long, and of a waste } \\
\text { source - sawdust. Measurements of the selected properties were } \\
\text { carried out on pellets with a diameter of } 6 \text { and } 8 \mathrm{~mm} \text {. Mechanical } \\
\text { durability, humidity, crumble rate, ash quantity, calorific value were } \\
\text { determined, as well as macronutrient and heavy metals content. The } \\
\text { calorific value of pellets, with moisture content from } 7.48 \% \text { to } 6.76 \% \\
\text { and ash content from } 0.31 \% \text { to } 0.55 \% \text {, ranged from } 17.71-19.18 \\
\mathrm{MJ} \cdot \mathrm{kg}^{-1} \text {, which testified to the beneficial energy use of the tested raw } \\
\text { material. Based on the conducted research, it was found that the } \\
\text { mechanical properties of pellets made of both sawdust and hard wood } \\
\text { predispose them for use as boiler fuel. The tested materials met high } \\
\text { quality standards for wood pellets used for non-industrial and industri- } \\
\text { al purposes. }\end{array}$} \\
\hline $\begin{array}{l}\text { Key words: } \\
\text { biomass, } \\
\text { pellets, } \\
\text { mechanical strength, } \\
\text { calorific value }\end{array}$ & \\
\hline
\end{tabular}

\section{Introduction}

The increase in energy consumption is associated with environmental pollution caused mainly by the burning of fossil fuels for heating and electricity production (Wójcicki, 2011). This forces many countries to produce electricity from renewable energy sources (RES), which do not affect adversely the environment as much as fossil fuels (Niedziółka, 2012). The European Union is going further in reducing gas emissions by increasing the share of RES in energy production. The effect of the European Council's efforts to combat global warming was to set quantitative targets, commonly known as "3x20", and to adopt the energy and climate package in December 2008 (Kowalke and Prochownik, 2014). The package stipulates that during this period the EU should: 1) reduce greenhouse gas emissions by $20 \%$ (compared to the 1990 levels), achieve a 20\% share of energy from RES in 
the total power consumption in the EU, and to increase energetic efficiency by $20 \%$ (Duda et al., 2009).

For Poland, renewable energy development has become a priority, both in the context of energy security and EU's environmental requirements. Publishing the energy and climate package Directive 2009/28/EC of the European Parliament and of the Council of 23 April 2009 on the promotion of the use of energy from renewable sources and amending and subsequently repealing Directives 2001/77/EC and 2003/30/EC set a new target for the EEC to reach a $20 \%$ share of energy from RES in total energy consumption by 2020 . As part of the adopted document on RES, the European Commission set a goal of a $15 \%$ share of "green" energy (including biofuels) in total energy consumption for Poland by 2020 (MG, 2009). In terms of searching for new solutions employed to obtain energy from RES, energy use of plant biomass enjoys a constant interest. This leads to a growing demand for this raw material, and increasing interest in its processing (Kraszkiewicz et al., 2013). The advantages of using biomass in the energy sector include: general availability of raw material, zero $\mathrm{CO}$ emissions, 2 , the lesser degree of unreliability compared to the production of wind and solar energy, safer transportation compared to oil and gas, the possibility of using wastelands for energy crop cultivation and the chance to create new jobs in rural areas (Olkuski and Stala-Szlugaj, 2018)

\section{Purpose of research}

The aim of the presented research was to determine and analyze selected quality features of 5 types of pellets. Selected mechanical and chemical properties of pellets were evaluated, taking into account the calorific value of the pellets, their durability and content of selected chemical elements in view of their practical use as boiler fuel.

\section{Material and research methods}

The research material was the following group: pellets (P1) with a diameter of $6 \mathrm{~mm}$, produced in $70 \%$ from coniferous sawdust and in $30 \%$ from deciduous sawdust, and pellets (P2) with a diameter of $8 \mathrm{~mm}$ made from $100 \%$ hard wood (beech, oak) by the company "Bioenergy Group". Pellets (P3) and (P4) with a diameter of $6 \mathrm{~mm}$ and $8 \mathrm{~mm}$ obtained from hardwood sawdust ( $98 \%$ beech). The producer of $\mathrm{P} 3$ and $\mathrm{P} 4$ pellets was the company "Biomasa" M. Małczyńska. Another test material was pellet (P5) with a diameter of $6 \mathrm{~mm}$, made $100 \%$ from coniferous sawdust. Pellets (P5) were purchased in one of the commercial chains dealing in the distribution of solid fuels.

\section{Methodology of static pellet testing}

Strength tests of the pellet samples were carried out on a Zwick/Roell Z010 testing machine (Fig. 1) in the laboratory of the Department of Food and Agriculture Production Engineering of the University of Rzeszow.

For uniaxial compression of individual pellets (a selected pellet with characteristics typical of the analyzed samples, ranging from 19 to $21 \mathrm{~mm}$ ), measured were 10 samples in 3 series of 5 analyzed types of pellets. After the measurements were taken, the damaged samples were weighed and placed in a dryer to determine the water content, separately for 
Analysis of selected quality...

each pellet. During the measurement, compressive (destructive) force $F_{\max }$ was applied to each pellet sample until the material was completely cracked or destroyed, to evaluate its mechanical strength. Recorded were the destructive force $\mathrm{F}_{\max }$, maximum deformation until destruction $\mathrm{L}_{\max }$. standard deviation $\mathrm{S}$, and the coefficient of variance $\mathrm{V}$. After each series of measurements, a printout was made with calculations of the mean values of the maximum force $\mathrm{F}_{\max }$, deformation until destruction $\mathrm{L}_{\max }$, energy $\mathrm{W}$, destructive stress $\sigma$ and the arbitrary elastic modulus $\mathrm{E}_{\mathrm{u}}$.

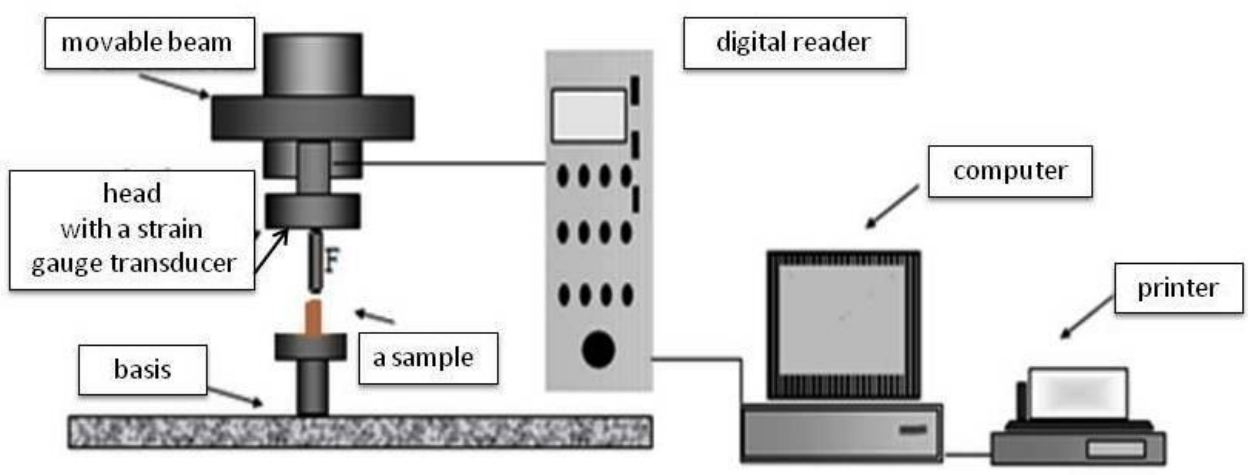

Figure 1. A schematic diagram of the Zwick/Roell measuring station

\section{Methodology of dynamic pellet testing}

The pellet mechanical strength test was carried out in the Tumbler 1000 device, according to PN-EN ISO 17831-1: 2016-02 (Fig. 2) on the laboratory stand located in the premises of the "Bio Energy Group" in Żołynia.

During the preparations for measuring the mechanical strength of the pellet using the Tumbler 1000 device (Fig. 2), each type of sample was delivered to the laboratory in bags. Sampling and preparation of the test samples were carried out according to PN-EN ISO 18135: 2017-06 and PN-EN ISO 14780: 2017 standards. Ready samples of each type of raw material were poured into a steel cylinder (Fig. 3).

Durability was measured in 5 types of pellet, in triplicate. The initial value of the mass of the tested raw material was $500 \mathrm{~g}$. The working time of the Tumbler 1000 device during a single test was 10 minutes at $500 \mathrm{rpm}^{-1}$ to $0 \mathrm{rpm}^{-1}$. With time, the value of revolutions was decreasing. A stainless steel cylinder and a $3.15 \mathrm{~mm}$ round sieve were used to properly conduct the test.

The mechanical strength of the pellets was calculated from the formula:

$$
D u=\frac{M a}{M e} \cdot 100
$$

where:

$\mathrm{Du} \quad-$ mechanical strength of the pellets, $(\%)$,

Ma - pellet mass before the test, $(\mathrm{g})$,

Me - pellet mass after the test, (g). 


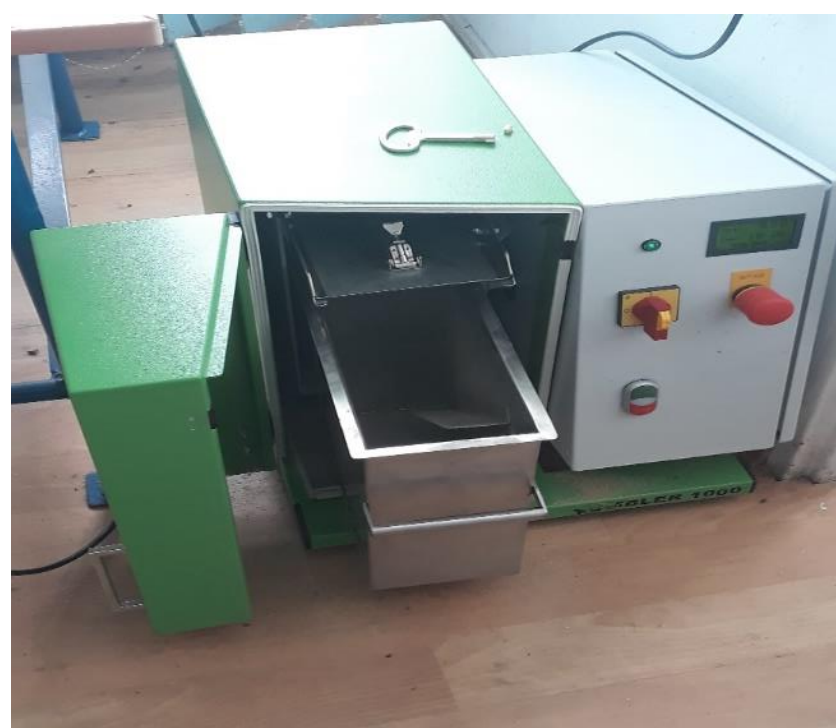

Figure 2. Tumbler 1000 device in the laboratory of "Bio Energy Group" in Żotynia
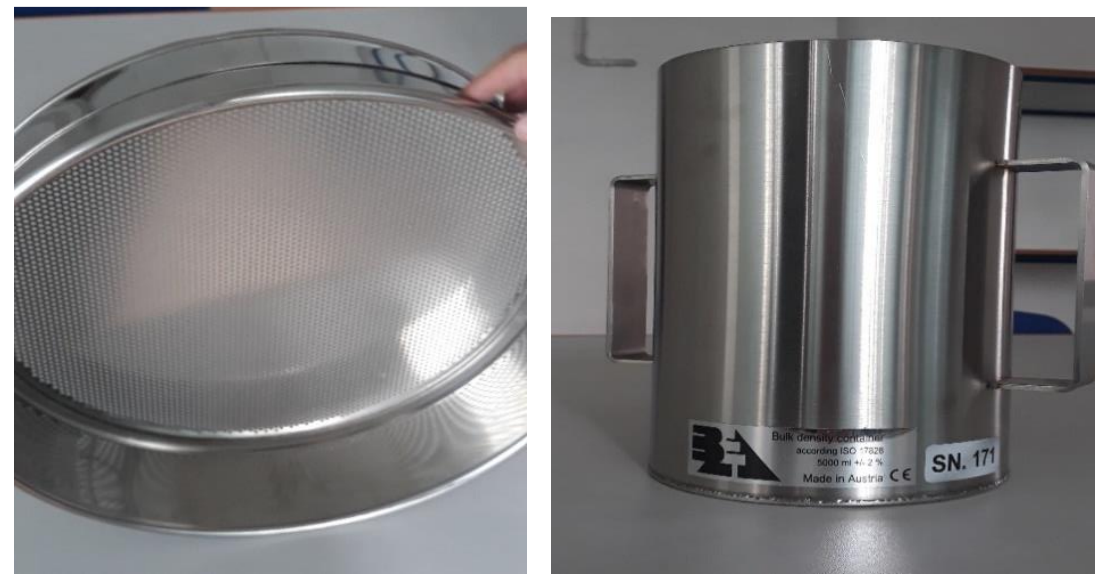

Figure 3. A 5 l stainless steel cylinder and a round sieve with $3.15 \mathrm{~mm}$ mesh diameter, $400 \times 100 \mathrm{~mm}$

\section{Humidity measurement}

After conducting the static pellet test (compression), the damaged material was used for measuring the water content in the raw material. The pellets were weighed with a laboratory scale, and then dried with a drying scale in the laboratory of the University of Rzeszow. The tests were carried out according to PN-EN ISO 18134-1: 2015-11. After drying, the samples were weighed again. 
Analysis of selected quality...

Their water content was calculated from the following formula:

$$
w=\frac{m_{1}-m_{2}}{m_{2}} \cdot 100 \%
$$

where:

$\mathrm{m}_{1} \quad$ - weight of the sample before drying, $(\mathrm{g})$

$\mathrm{m}_{2} \quad$ - weight of the sample after drying, $(\mathrm{g})$

W - humidity, (\%)

\section{Methodology for determining ash content and calorific value}

Ash content in the material intended for thermogravimetric tests was determined according to PN-EN ISO18122: 2016-01 using the LECO - TGA701 device. The changes in the mass of the tested sample were determined, which were the result of applying temperatures of $150,200,250$ and $300^{\circ} \mathrm{C}$ for 30 minutes. Using a thermogravimetric scale (drying scale), the change in the mass of the test sample was measured, depending on the temperature changes. The second part of the material was dried $\left(\right.$ at $\left.70^{\circ} \mathrm{C}\right)$ in a laboratory dryer with forced air circulation for about 4 hours. After fully drying of the sample, the material was ground using a ball mill. Part of the thus prepared material was used to make $1 \mathrm{~g}$ tablets used for calorimetric tests. The calorific test was carried out using a LECO AC500 calorimeter according to PN-EN ISO 18125: 2017-07.

\section{Chemical composition}

The samples were ground and mineralized in a microwave oven in $65 \%$ nitric acid using an Ethos One mineralizer. The mineralization process consisted of 5 stages. In the first stage, the temperature inside the crucible increased from ambient temperature to $100^{\circ} \mathrm{C}$ within 5 minutes. The second stage was to maintain this temperature for another 10 minutes. In the third stage, the temperature was increased to $200^{\circ} \mathrm{C}$ for 10 minutes, and maintained for another 10 minutes, which marked the end of the fourth stage. The last stage was a gradual lowering of the temperature to under $50^{\circ} \mathrm{C}$ within 30 minutes. After the mineralization, the chemical composition of the material was analyzed on a spectrometer iCAP Dual 6500 by Thermo Scientific (USA). The total content of elements in the samples (the cation profile) was determined by atomic emission spectrometry with excited atomic plasma.

\section{Results}

The mechanical parameters determine the quality of the pellets, which is very important in terms of use as fuel for automatic boilers. Appropriate values of mechanical parameters determine the biomass resistance to disintegration during transport and affect its burning time.

The paper presents the results of static tests of 5 types of pellets which allow determining the quality of the tested biomass. 
Józef Gorzelany, Miłosz Zardzewiały, Piotr Murawski, Natalia Matłok

Table 1.

Mean values of selected mechanical properties of the tested plant biomass samples (pellets) in the process of their uniaxial compression (in a vertical axis)

\begin{tabular}{|c|c|c|c|c|c|c|c|c|}
\hline $\begin{array}{l}\text { Pellet } \\
\text { diameter } \\
\varnothing(\mathrm{mm})\end{array}$ & $\begin{array}{c}\text { Type of } \\
\text { pellet }\end{array}$ & $\begin{array}{l}F_{\max } \\
(\mathrm{N})\end{array}$ & $\begin{array}{c}\mathrm{L}_{\max } \\
(\mathrm{mm})\end{array}$ & $\begin{array}{l}\text { W do } \\
F_{\max } \\
(\mathrm{mJ})\end{array}$ & $\begin{array}{c}\text { Breaking } \\
\text { stress } \\
\sigma \\
(\mathrm{MPa})\end{array}$ & $\begin{array}{c}\text { Relative de- } \\
\text { formation } \\
\varepsilon\end{array}$ & $\begin{array}{l}\text { Arbitrary } \\
\text { elastic mod- } \\
\text { ulus Eu } \\
\text { (MPa) }\end{array}$ & $\begin{array}{l}\mathrm{F}_{\max } / \mathrm{L}_{\max } \\
\left(\mathrm{N} \cdot \mathrm{mm}^{-1}\right)\end{array}$ \\
\hline \multirow[b]{2}{*}{6} & $\mathrm{P} 1$ & $\begin{array}{l}166.98 \mathrm{a} \\
\pm 24.98\end{array}$ & $\begin{array}{l}1.02 \mathrm{a} \\
\pm 0.33\end{array}$ & $\begin{array}{l}97.26 \mathrm{a} \\
\pm 46.54\end{array}$ & $\begin{array}{c}5.9 \mathrm{a} \\
\pm 0.88\end{array}$ & $\begin{array}{l}0.051 \mathrm{a} \\
\pm 0.017\end{array}$ & $\begin{array}{l}122.47 \mathrm{c} \\
\pm 35.60\end{array}$ & $\begin{array}{l}175.4 \mathrm{a} \\
\pm 50.60\end{array}$ \\
\hline & P3 & $\begin{array}{c}395.42 \mathrm{~b} \\
\pm 94.23 \\
153.68 \mathrm{a} \\
\pm 32.95\end{array}$ & $\begin{array}{l}2.65 \mathrm{~b} \\
\pm 0.45 \\
1.61 \mathrm{a} \\
\pm 0.84\end{array}$ & $\begin{array}{l}639.3 \mathrm{~b} \\
\pm 122.9 \\
156.6 \mathrm{a} \\
\pm 112.9\end{array}$ & $\begin{array}{c}14.0 \mathrm{~b} \\
\pm 3.33 \\
5.4 \mathrm{a} \\
\pm 1.16\end{array}$ & $\begin{array}{l}0.131 \mathrm{c} \\
\pm 0.022 \\
0.080 \mathrm{~b} \\
\pm 0.045\end{array}$ & $\begin{array}{c}111.38 \mathrm{bc} \\
\pm 38.52 \\
82.27 \mathrm{ab} \\
\pm 32.42\end{array}$ & $\begin{array}{c}155.2 \mathrm{a} \\
\pm 53.54 \\
114.5 \mathrm{a} \\
\pm 44.53\end{array}$ \\
\hline 8 & $\mathrm{P} 2$ & $\begin{array}{c}574.42 \mathrm{~b} \\
\pm 56.22 \\
308.04 \mathrm{a} \\
\pm 39.60\end{array}$ & $\begin{array}{l}0.90 \mathrm{a} \\
\pm 0.22 \\
2.04 \mathrm{~b} \\
\pm 0.31\end{array}$ & $\begin{array}{l}270.3 \mathrm{a} \\
\pm 93.58 \\
398.4 \mathrm{~b} \\
\pm 74.35 \\
\end{array}$ & $\begin{array}{l}11.4 \mathrm{~b} \\
\pm 1.11 \\
6.12 \mathrm{a} \\
\pm 0.78\end{array}$ & $\begin{array}{l}0.046 \mathrm{a} \\
\pm 0.011 \\
0.105 \mathrm{c} \\
\pm 0.014\end{array}$ & $\begin{array}{c}257.53 \mathrm{~b} \\
\pm 60.85 \\
58.94 \mathrm{a} \\
\pm 11.31\end{array}$ & $\begin{array}{c}667.32 \mathrm{~b} \\
\pm 158.72 \\
154.44 \mathrm{a} \\
\pm 32.03\end{array}$ \\
\hline \multicolumn{2}{|c|}{ Mean X for P1-P5 } & $\begin{array}{l}335.52 \\
\pm 131.8 \\
\end{array}$ & $\begin{array}{c}1.57 \\
\pm 0.76 \\
\end{array}$ & $\begin{array}{c}299.7 \\
\pm 175.8 \\
\end{array}$ & $\begin{array}{r}8.39 \\
\pm 3.49 \\
\end{array}$ & $\begin{array}{c}0.08 \\
\pm 0.036 \\
\end{array}$ & $\begin{array}{r}132.97 \\
\pm 74.53 \\
\end{array}$ & $\begin{array}{c}284.29 \\
\pm 170.49 \\
\end{array}$ \\
\hline
\end{tabular}

* $\mathrm{x} \pm \mathrm{Sd}, \mathrm{x}-$ mean, sd- standard deviation, and - no significant statistical differences; the pellets were characterized by varied mechanical strength.

For the analyzed humidity, the mean value of the destructive force $F_{\max }$ for pellets with a diameter of $6 \mathrm{~mm}(\mathrm{P} 1, \mathrm{P} 3, \mathrm{P} 5)$ was $222.85 \mathrm{~N}$, whereas for pellets with a diameter of $8 \mathrm{~mm}$ (P2 and $\mathrm{P} 4), 448.19 \mathrm{~N}$.

Upon analyzing the values of energy required for pellet destruction ( $W$ to $F_{\max }$ ), for pellets with a diameter of $6 \mathrm{~mm}$, the lowest value of energy needed to destroy the sample was recorded for P1 $(97.26 \mathrm{~mJ})$, and the highest for P3 pellets $(639.3 \mathrm{~mJ})$. The values of the analyzed parameter for pellets with a diameter of $8 \mathrm{~mm}$ were, respectively, $270.3 \mathrm{~mJ}$ for P2 and $398.4 \mathrm{~mJ}$ for $\mathrm{P} 4$.

Mean values of the destructive stress in the vertical uniaxial compression for pellets with a diameter of $6 \mathrm{~mm}$ was $7.88 \mathrm{MPa}$, and in pellets with a diameter of $8 \mathrm{~mm}, 8.91 \mathrm{MPa}$. Mean values of the conventional elastic modulus Eu differed significantly, regardless of the pellet diameter and water content, and ranged from 82.27 MPa for P5 pellet to 257.53 MPa for $\mathrm{P} 2$ pellet.

Wang et al. (1997) reported the value of the elastic modulus of wood pellets produced with the addition of various types of plasticizers ranging from $160 \mathrm{MPa}$ for pellets without the addition of plasticizers to $60 \mathrm{MPa}$ for pellets with a $40 \%$ share of plasticizers. According to Novákova and Brožek (2008) the obtained values of destructive force measurements $\left(\mathrm{F}_{\max } / \mathrm{L}_{\max }\right)$ of individual types of pellets produced from various combinations of ingredients such as grass, shells, tree bark, poplar and coal ranged from 440 to $2420 \mathrm{~N} \cdot \mathrm{mm}^{-1}$. 
Analysis of selected quality...

Table 2

Biomass durability results and crumble rate using the Tumbler 1000 device

\begin{tabular}{lcc}
\hline Name of material & $\begin{array}{c}\text { Durability of the pellets } \\
(\%)\end{array}$ & $\begin{array}{c}\text { Crumble rate } \\
(\%)\end{array}$ \\
\hline P1 & 97.92 & 2.08 \\
P2 & 97.96 & 2.04 \\
P3 & 98.32 & 1.68 \\
P4 & 95.74 & 4.26 \\
P5 & 98.66 & 1.34 \\
\hline
\end{tabular}

The results of the durability tests of individual types of biomass in the form of pellets are very similar to each other. The highest biomass durability (Table 2) was recorded for P5 pellets, $98.66 \%$, which has the lowest crumble rate, $1.34 \%$. The lowest biomass durability (Table 2) was recorded for P4 pellets, $95.74 \%$, which has the highest crumble rate, $4.26 \%$.

Results obtained by Miranda et al. (2015) for various pellets demonstrate biomass stability at $94.4-98.8 \%$, with the crumble rate from 1.2 to $5.6 \%$ (water content ranged from 6 to $10 \%$ ). Rynkiewicz (2013) obtained biomass durability results of $98-99 \%$ with a moisture content of $10 \%$ for four types of pellets from deciduous trees.

Table 3.

Mean values of the analyzed parameters of plant biomass in the form of pellets

\begin{tabular}{lccc}
\hline Pellet name & $\begin{array}{c}\text { Moisture content } \\
(\%)\end{array}$ & $\begin{array}{c}\text { Ash content } \\
(\%)\end{array}$ & $\begin{array}{c}\text { Calorific value } \\
\text { of biomass } \\
\left(\mathrm{MJ}^{\mathrm{kg}} \mathrm{kg}^{-1}\right)\end{array}$ \\
\hline P1 & 6.85 & 0.31 & 19.18 \\
P2 & 6.76 & 0.33 & 18.06 \\
P3 & 7.28 & 0.47 & 17.71 \\
P4 & 6.80 & 0.55 & 18.06 \\
P5 & 7.48 & 0.36 & 18.72 \\
\hline
\end{tabular}

Analysis of the results of the tested biomass (Table 3) shows that all types of pellets have a high calorific value, with the highest value for P1 pellet, $19.18 \mathrm{MJ} \cdot \mathrm{ha}^{-1}$, and the lowest for P3 pellet, $17.71 \mathrm{MJ} \cdot \mathrm{kg}^{-1}$. The obtained calorific value is comparable to the results of Niedziółka and Zuchniarz (2006), who determined the calorific value of biomass pellets at $17.3 \mathrm{MJ} \cdot \mathrm{kg}^{-1}$ with humidity ranging from 3.6 to $12 \%$. The differences result from the different water content of individual materials and the composition of the pellets.

The percentage of ash content in selected pellets does not exceed $1 \%$. The minimum value of $0.31 \%$ is for $\mathrm{P} 1$ pellets, and the maximum value of $0.55 \%$, for $\mathrm{P} 4$ pellets. Niedziółka and Zuchniarz (2006) indicate that biomass combustion results in small amounts of ash, from 0.5 to $12.5 \%$. If the ash value is higher, this indicates fuel pollution.

The analyzed samples of pellets were characterized by different water content. Measurements of the calorific value carried out during the assessment indicate the lowest water content in P2 pellet, and the maximum in P5 pellet, $6.76 \%$ and $7.48 \%$, respectively. 
Józef Gorzelany, Miłosz Zardzewiały, Piotr Murawski, Natalia Matłok

Niedziółka et al. (2008) reported the moisture content for pellets from 5 to $12 \%$, Dreszer et al. (2003) demonstrated that the moisture content of straw materials between 10 and $20 \%$.

Table 4.

The content 7 of selected chemical elements in five types of pellets

\begin{tabular}{|c|c|c|c|c|c|}
\hline $\begin{array}{l}\text { Name } \\
\text { of the chemical } \\
\text { element }\end{array}$ & $\begin{array}{l}\text { Pellet P1 } \\
\left(\mathrm{mg} \cdot \mathrm{kg}^{-1}\right)\end{array}$ & $\begin{array}{l}\text { Pellet P2 } \\
\left(\mathrm{mg} \cdot \mathrm{kg}^{-1}\right)\end{array}$ & $\begin{array}{l}\text { Pellet P3 } \\
\left(\mathrm{mg} \cdot \mathrm{kg}^{-1}\right)\end{array}$ & $\begin{array}{l}\text { Pellet P4 } \\
\left(\mathrm{mg} \cdot \mathrm{kg}^{-1}\right)\end{array}$ & $\begin{array}{l}\text { Pellet P5 } \\
\left(\mathrm{mg} \cdot \mathrm{kg}^{-1}\right)\end{array}$ \\
\hline Arsenic & 0.00 & 0.00 & 0.00 & 0.00 & 0.00 \\
\hline Cadmium & 0.20 & 0.075 & 0.10 & 0.13 & 0.20 \\
\hline Copper & 0.00 & 0.00 & 0.00 & 0.18 & 0.00 \\
\hline Nickel & 0.00 & 0.00 & 0.00 & 5.38 & 0.00 \\
\hline Lead & 0.00 & 0.00 & 0.00 & 0.53 & 0.05 \\
\hline Potassium & 359.00 & 723.50 & 1361.10 & 1382.80 & 391.70 \\
\hline Sodium & 1.40 & 15.40 & 0.70 & 3.25 & 4.10 \\
\hline Sulfur & 44.10 & 100.40 & 175.00 & 140.17 & 72.40 \\
\hline Magnesium & 174.0 & 105.70 & 358.20 & 445.80 & 189.10 \\
\hline
\end{tabular}

The obtained results (Table 4) on the content of selected heavy metals in individual types of biomass are lower than the values given in the literature by Szwalc et al. (2016) and Poluszyńska and Ślęzak (2015). There was no arsenic in the analyzed types of pellets, while cadmium was found in all types of pellets in trace amounts. Of the five types tested, the highest sulfur content was observed in P3 and P4 pellets, made in $98 \%$ of beech wood sawdust.

\section{Summary and conclusions}

The research showed that in terms of their energy use, the selected quality features of the tested pellets were beneficial and desirable. It should also be noted that the tested materials met high quality standards for wood pellets used for non-industrial and industrial purposes (PN-EN ISO 17225-2: 2014-07).

The high durability and energy value of the tested pellets puts these raw materials at the forefront of solid biofuels. This was also confirmed upon comparing the obtained results with the data presented by other authors. Based on the analysis of the obtained research results, the following statements and conclusions can be made:

1. The mean calorific value of the five pellets tested was $18.34 \mathrm{MJ} \cdot \mathrm{kg}^{-1}$ with a water content between $6.80 \%$ and $7.48 \%$, which in terms of their energy use is beneficial for the combustion process.

2. The mean values of the destructive force of the analyzed pellets in the uniaxial compression process (in the vertical axis) varied depending on the producer and the diameter of the pellet, and were as follows:

- for pellets with a diameter of $6 \mathrm{~mm}, \mathrm{~F}_{\max }$ ranged from $153.68 \mathrm{~N}$ (P5) to $395.42 \mathrm{~N}$ (P3),

- for pellets with a diameter of $8 \mathrm{~mm}, \mathrm{~F}_{\max }$ ranged from $308.06 \mathrm{~N}(\mathrm{P} 4)$ to $574.32 \mathrm{~N}$ (P2). 
Analysis of selected quality...

3. Irrespective of the pellet diameter and water content, the values of the conventional elastic modulus $\mathrm{Eu}$ in the uniaxial biomass compression process varied significantly, from 82.27 MPa ( $\mathrm{P} 5$ pellets) to $257.53 \mathrm{MPa}$ ( $\mathrm{P} 2$ pellets).

4. In dynamic strength tests of the analyzed pellets, conducted using the Tumbler 1000 device, the highest strength was observed for P3 and P5 pellets (over 98\%), and the lowest, for P4 pellet (95.7\%), because it contained the largest amount of dust and crumbs.

5. The analyzed pellet samples contained a low amount of ash. After biomass combustion, the highest residue content was observed in $\mathrm{P} 4$ pellets $-0.55 \%$, and the lowest, in P1 $-0.31 \%$.

\section{References}

Dreszer, K., Michałek, R., Roszkowski, A. (2003). Energia odnawialna - możliwości jej pozyskania $i$ wykorzystania $w$ rolnictwie. Polskie Towarzystwo Inżynierii Rolniczej. Kraków-LublinWarszawa.

Duda, M., Mikołajuk, H., Okrasa, S. (2009). Prognoza bilansu energetycznego Polski do 2030 r. Materiały XXIII konferencji. Zagadnienia surowców energetycznych i energii w gospodarce krajowej. Zakopane. Poland.

Kowalke, K., Prochownik, M. (2014). Wpływ pakietu energetyczno-klimatycznego na proces unowocześniania polskiego sektora energetycznego. Zarzadzanie i Finanse Journal of Management and Finance, 12(4), 229-245.

Kraszkiewicz, A., Kachel-Jakubowska, M., Szpryngiel, M. (2013). Analiza wybranych cech jakościowych peletów wytworzonych z surowców roślinnych. Inżynieria Rolnicza, 2(143), 167-173.

Ministerstwo Gospodarki. (2009). Polityka energetyczna Polski do 2030 roku. Warszawa. Poland

Miranda, T., Montero, I., Sepúlveda, F.J., Arranz, J., A., Rojas, C.V., Nogales, S. (2015). Review of pellets from different sources. Materials, 8(4), 1413-1427.

Niedziółka, I., Zuchniarz, A. (2006). Analiza energetyczna wybranych rodzajów biomasy pochodzenia roślinnego. Motorol, 8a, 232-237.

Niedziółka, I., Szymanek, M., Zuchniarz, A., Zawiślak, K. (2008). Characteristic of pellets produced from selected plant mixes. Teka Komisji Motoryzacji i Energetyki Rolnictwa, 8, 157-162.

Niedziółka, D. (2012). Zielona energia $w$ Polsce. Warszawa. Wydawnictwo CeDeWu. ISBN 9788375564679

Nováková, A., Brožek, M. (2008). Mechanical properties of pellets from sorrel, in: Engineering for rural development. Latvia University of Agriculture, 29-30 May. Jelgava: Institute of Agricultural Energetic, Latvia University of Agriculture, 265-269.

Olkuski, T., Stala-Szlugaj, K. (2018). Międzynarodowy rynek pelletów drzewnych. Zeszyty Naukowe Instytutu Gospodarki Surowcami Mineralnymi i Energia PAN, 105, 75-84.

Poluszyńska, J., Slęzak, E. (2015). Charakterystyka popiołów ze spalania biomasy i ocena możliwości ich wykorzystania w celach przyrodniczych. Prace Instytutu Ceramiki i Materiałów Budowlanych, 23, 71-78.

PN-EN ISO 17831-1:2016-02 Oznaczanie wytrzymałości mechanicznej.

PN-EN ISO 14780:2017 Przygotowanie próbek.

PN-EN ISO 18135:2017-06 Pobieranie próbek.

PN-EN ISO 18134-1:2015-11 Oznaczanie zawartości wilgoci -metodą suszarkową.

PN-EN ISO 18122:2016-01 Oznaczanie zawartości popiołu.

PN-EN ISO 18125:2017-07 Oznaczanie wartości opałowej.

PN-EN ISO 17225-2:2014-07 Specyfikacje paliw i klasy -wymagania ogólne. 
Rynkiewicz, R. (2013). Fizyczne i mechaniczne właściwości peletów z trocin sosnowych z dodatkiem trocin drzew liściastych. Inżynieria Rolnicza, 2(163), 299-306.

Szwalec, A., Mundała, P., Kędzior, R., Telk, M., Gawroński, P. (2016). Zróżnicowanie zawartości $\mathrm{Cd}, \mathrm{Pb}, \mathrm{Zn}$ i $\mathrm{Cu}$ w biomasie wykorzystywanej na cele energetyczne. Acta Scientiarum Polonorum Formatio Circumiectus, 15(4), 343-351.

Wang, Ch., Zhang, G., Shah, N.H., Infeld, M., Malick, A., McGinity, J. (1997). Influence of plasticizers on the mechanical properties of pellets containing Eudragit ${ }^{\circledR}$ RS 30 D. International Journal of Pharmaceutics, 152, 153-163.

Wójcicki, Z. (2011) Energia odnawialna i ochrona środowiska wiejskiego. Infrastruktura i ekologia terenów wiejskich, 1, 7-15.

\section{ANALIZA WYBRANYCH CECH JAKOŚCIOWYCH PELETÓW WYTWORZONYCH Z SUROWCA DRZEWNEGO}

Streszczenie. W artykule przedstawiono analizę właściwości energetycznych, mechanicznych oraz chemicznych peletów wytworzonych z surowca drzewnego. Pelety wg. informacji producenckich wyprodukowano $\mathrm{z}$ twardego drewna rozdrobnionego do frakcji o grubości około $1 \mathrm{~mm}$ i o długości do 3-4 mm oraz z surowica odpadowego-trocin. Pomiary wybranych właściwości przeprowadzono na peletach o średnicy 6 i $8 \mathrm{~mm}$. Określono trwałość mechaniczną, wilgotność, straty okruszenia, ilość popiołu, wartość opałową oraz zawartość makroskładników i metali ciężkich. Wartość opałowa peletów o zawartości wilgotności od $7,48 \%$ do $6,76 \%$ i zawartości popiołu od $0,31 \%$ do $0,55 \%$ była w zakresie od 17,71-19,18 MJ $\mathrm{kg}^{-1}$ i świadczyła o korzystnym wykorzystaniu energetycznym badanego surowca. Na podstawie przeprowadzonych badań stwierdzono, że właściwości mechaniczne peletów wytworzonych zarówno z trocin jak i z twardego drewna predysponują je do zastosowania jako paliwo kotłowe. Badane materiały spełniały wysokie jakościowe normy obowiązujące dla peletów drzewnych stosowanych do celów nieprzemysłowych i przemysłowych.

Słowa kluczowe: biomasa, pelety, wytrzymałość mechaniczna, wartość opałowa 